\title{
The Criteria For Decision Making In Adaptive Reuse Towards Sustainable Development
}

\author{
Noorzalifah Mohamed ${ }^{1, a}$ and Kartina Alauddin ${ }^{1}$ \\ ${ }^{1}$ Faculty of Architecture, Planning and Surveying, Universiti Teknologi MARA (Perak), Seri Iskandar, 32610 Perak, Malaysia
}

\begin{abstract}
Adaptive reuse is an important strategy for achieving sustainability as it ensures a continuous building life cycle and prevents building destruction. Adaptive reuse has the greatest potential to lower the environmental load of the built environment significantly within the next 20 to 30 years. But, the owners and practitioners still lack of point of references to justify and evaluate their decision making with regard to the adaptation practice. The aim of this paper is to explore the unique criteria of decision making among practitioners in the application of adaptive reuse of existing buildings. The descriptive study has identified five main criteria influenced in decision making in adaptive reuse that effected to the sustainable development; economic, environment, social, legislative and architecture. We designed a questionnaire to determine the most significant criteria in decision making for adaptive reuse towards sustainable development among practitioners. The paper describes the process in identifying the unique criteria and the proposed methodology for the study.
\end{abstract}

\section{Introduction}

The climate change has led to significant carbon emission reduction strategy and low carbon urban planning. With the construction of the new building will use a large amount of raw materials and energy, and generates high carbon emissions (Langston, 2011; Gorgolewski, 2008). According to Zuo and Zhao (2014), buildings are responsible for $40 \%$ of total energy consumption and produce greenhouse gas emission which is responsible for global warming issues during their life cycle. In terms of waste per year, building construction produce for about 136 million tons of waste, almost half of it from demolition and this also lead to the use of large amounts of raw materials and a huge environmental damage (Gorgolewski, 2008; Rashid et al. 2015). Given these figures, the construction sector has critical to reduce carbon emissions significantly.

Malaysia intends to be a developed country by 2020 and the criteria that need to be achieved are to have the construction of low-carbon emission, sustainable and inclusive, and efficient use of resources. Thus, the new buildings with green requirement are growing rapidly. However, the sustainability cannot be achieved unless the existing building stock is being addressed carefully. This because, even every new building was a 'green building' but their impact on sustainability as a whole will be minimal for some while (Adeyemi et al., 2014).

Therefore, it is important to consider the existing building stock in a sustainable development. As a developing country, Malaysia has a large stock of existing buildings and most of these buildings were not conserved well and most of them were in poor conditions and invaluable (Ahmad, 2009). To address the problem, adaptive reuse of existing buildings is seen as an important strategy for achieving sustainability. This is because, adaptive reuse can extend the life of buildings and avoid demolition wastes, promote reuse of contained energy and also provide environmental, social and economic benefits to the community (Yung and Chan, 2012). While the benefit of adaptive reuse widely espoused, however, it would appear that owners and practitioners still lack a point of reference to justify and evaluate their decision making with regard to the adaptation of adaptive reuse of existing buildings (Bullen and Love, 2011b). Douglas (2006) ague that decision making is complex in the adaptive reuse building because there are many parties involved in the adaptation and each party presents a different perspective. According to Yau (2010) most existing buildings in Malaysia were not categorized into the green responsive building. This is shown by low numbers (10 out of 21$)$ of an adaptive

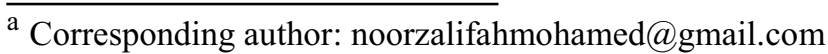


reuse project that had been certified by Green Building Index (GBI) (see Table 1). Therefore, the role of industrial players is important to improve the number of adaptive reuse projects to increase the foregoing numbers. Thus, there is an urgent need to understand how practitioner or industry players make decision to adapt the green concept into adaptive reuse of existing building.

This study is still in progress. This paper described the literature review and the development of questionnaires for data collection. The data collection process is in between December 2015 and January 2016.

Table 1. Number of GBI Certified Projects by Category

\begin{tabular}{|c|c|c|c|c|c|c|c|}
\hline $\begin{array}{l}\text { Update on } \\
\text { GBI }\end{array}$ & $\begin{array}{l}\text { Total as } \\
\text { of } 15 \\
\text { Dec } 2015\end{array}$ & $\begin{array}{l}\text { NRNC } \\
\text { Non } \\
\text { Residential } \\
\text { New } \\
\text { Construction }\end{array}$ & $\begin{array}{l}\text { RNC } \\
\text { Residential } \\
\text { New } \\
\text { Construction }\end{array}$ & $\begin{array}{l}\text { INC } \\
\text { Industrial } \\
\text { New } \\
\text { Construction }\end{array}$ & \begin{tabular}{|l|} 
NREB \\
Non \\
Residential \\
Existing \\
Building \\
\end{tabular} & $\begin{array}{l}\text { IEB } \\
\text { Industrial } \\
\text { Existing } \\
\text { Building }\end{array}$ & $\begin{array}{l}\mathrm{T} \\
\text { Township }\end{array}$ \\
\hline Applied & 707 & 369 & 276 & 20 & 21 & 4 & 17 \\
\hline Registered & 664 & 341 & 264 & 19 & 21 & 3 & 17 \\
\hline $\begin{array}{l}\text { Total } \\
\text { Certified }\end{array}$ & $\begin{array}{c}335 \\
310 \% \%\end{array}$ & $\begin{array}{c}168 \\
650 \%\end{array}$ & $\begin{array}{c}138 \\
41 \%\end{array}$ & 9 & 10 & 3 & $\begin{array}{c}7 \\
0 \%\end{array}$ \\
\hline $\begin{array}{l}\text { Received } \\
\text { with } \\
\text { Provisional } \\
\text { Certification } \\
\text { after DA }\end{array}$ & 283 & 143 & 121 & 5 & 6 & 1 & 7 \\
\hline $\begin{array}{l}\text { Received } \\
\text { Final } \\
\text { Certification } \\
\text { after CVA }\end{array}$ & 51 & 24 & 17 & 4 & 4 & 2 & - \\
\hline $\begin{array}{l}\text { Received } \\
\text { Renewal } \\
\text { Certification } \\
\text { after RVA }\end{array}$ & 1 & 1 & - & - & - & - & - \\
\hline
\end{tabular}

Source: Green Building Index (GBI), 2015

\section{Adaptive Reuse Terminologies}

Adaptive reuse usually refers to the reuse of the site or building for the purposes other than those originally intended or designed for. According to Enache (2014), adaptive reuse of buildings is one of the most important practices in order to maintain existing buildings, by changing its purpose, after the structure has reached its level of maturity within the life cycle. These new users can offer economic, social and cultural benefits to their environment. In additional, the adaptive reuse is one approach to sustainability where it kept the durability of the original building materials and reduced its carbon footprints. Adaptive reuse addresses issues of conservation and preservation of the built heritage, as well as strategies and policies. Once the old structures become inadequate to their functional and programmatic needs, adaptive reuse becomes a sustainable option for reclamation of sites.

Adaptation is derived from the Latin word 'ad' means (to) while 'Aptar' is (fit). Usually the definition of adaptation refers to a 'change of use', 'retention' of the original structure and fabric of the building and also extends the 'life expectancy' of the property of the person (Douglas, 2006; Bullen, 2007). In the context of building, adaptive reuse is a term that has been interpreted widely and is defined by many researchers (Douglas 2006, Bullen, 2007). There are different interpretations for "adaptive reuse" known as conversion, retrofitting, adaptation, refurbishment, rehabilitation and etc. (Langston, 2011; Douglas, 2006). According to Bullen (2007), adaptive reuse is a 'rehabilitation, renovation or restoration work that does not necessarily involve a change of use' and it will 'extend the useful life and sustainability in a combination of improvement and conversion'. Wilkinson and Reed (2008) defined adaptive as activity in maintaining as much of the original as possible, improve performance with modern standards and needs changing. They also state that refurbishment is a 'conversion describing a change in use'. Therefore, some the term refurbishment and adaptive reuse could mean the same thing.

\section{Decision Making Issues}

In previous studies, many researchers argue that the decision making to adaptive reuse of existing buildings is a complex stage (Douglas, 2006; Wilkinson and Reed, 2009; Alauddin, 2014). This is because there are many stakehoders involved in making decisions and each party has a different view. Those involved in the adaptation decision making are the owners, developers, producer, investors, regulators and marketers. They come from a variety of backgrounds and when the building adaptation be considered, it has triggered a range of views and perspectives based on their choice (Wang and Zeng, 2010). For example the building owner that wants to adapt the building will look into the financial resources they have. Investors want to see the future to build and marketers look to the latest market demands. Producer (professional team) will correlate with original architecture, structure, function, space and others when making a decision to reuse the building. In addition, another layer of complexity is when the stakeholders involved in the process of decision making at various levels and each had different degrees of influence (Alauddin and London, 2011). Furthermore the ability of stakeholders to influence the decision can be classified as either directly or indirectly. Thus, when a decision is made at the beginning of the process it will affect continue throughout the project. The desire of an organization that aspires to be the occupier or user of the building is yet another layer of complexity. This is due to the decisions taken will affect the activities or operations in the building. (See Table 2)

Table 2. Decision agent for adaptation of existing buildings (Adapted Wilkinson and Reed 2009)

\begin{tabular}{|l|l|l|}
\hline Decision agents & $\begin{array}{l}\text { Description \& Professional } \\
\text { Affiliations }\end{array}$ & $\begin{array}{l}\text { Stage in } \\
\text { adaptation } \\
\text { where decisions } \\
\text { made }\end{array}$ \\
\hline Investors & $\begin{array}{l}\text { Pension/ super funds, insurance } \\
\text { companies, banks, independant } \\
\text { investors, professionals who } \\
\text { find capital to invest }\end{array}$ & Beginning/ early \\
\hline
\end{tabular}




\begin{tabular}{|l|l|l|}
\hline Producers & $\begin{array}{l}\text { Professional team- PM, QS, } \\
\text { Architects, Engineers, } \\
\text { contractors, surveyors, } \\
\text { suppliers (RICS, AIAA, AIQS, } \\
\text { AIBS, Fire engineers, structural } \\
\text { and M\&E engineers) }\end{array}$ & $\begin{array}{l}\text { QS/A at } \\
\text { feasibility stage } \\
\text { Design stage } \\
\text { Construction } \\
\text { stage }\end{array}$ \\
\hline Marketeers & $\begin{array}{l}\text { Surveyors, agents, professional } \\
\text { who find users for buildings } \\
\text { (API, RICS) }\end{array}$ & $\begin{array}{l}\text { During the design } \\
\text { (if selling off } \\
\text { plan) and/ or } \\
\text { Construction } \\
\text { stage }\end{array}$ \\
\hline Regulators & $\begin{array}{l}\text { Local Authorities, Planners, } \\
\text { Heritage, Building Surveyors, } \\
\text { Fire engineers (PIA) }\end{array}$ & $\begin{array}{l}\text { During the design } \\
\text { stage (and } \\
\text { possibly during } \\
\text { construction if } \\
\text { amendments are } \\
\text { made) }\end{array}$ \\
\hline Policy makers & $\begin{array}{l}\text { Federal, State and Local } \\
\text { Government departments }\end{array}$ & $\begin{array}{l}\text { Indirect effect on } \\
\text { decision making } \\
\text { in adaptation at } \\
\text { all stages }\end{array}$ \\
\hline Developers & $\begin{array}{l}\text { Organizations who combine } \\
\text { investment, production \& } \\
\text { marketing in whole or in part. } \\
\text { Professionals from above } \\
\text { bodies and others }\end{array}$ & $\begin{array}{l}\text { Beginning/ early } \\
\text { users individuals }\end{array}$ \\
\hline $\begin{array}{l}\text { Users-Corporate } \\
\text { Residential }\end{array}$ & $\begin{array}{l}\text { Large institional owners and } \\
\text { users }\end{array}$ & \\
\hline
\end{tabular}

The next aspect is the range of options available to the stakeholders such as to change the use to a minimum because of the involvement of 'flexibility' is in the building as there was the first choice. The second choice has for small changes and adjustments to the third option required a higher level of engagement and are usually referred to as the 'reform' or 'retrofitting'. The fourth option involves the demolition while the fifth is an extension of the facility. Finally, the sixth is the demolition and redevelopment and selected when the economic, environmental and social conditions, physical and regulations are such that the building is said to be at the end of the life cycle and lack of utilities (Wilkinson, 2011).

\section{Research Questions}

Based on the issues raised in the literature review, research questions have been established as part of this research are:

1) What are the criteria of decision making among industrial players in the application of adaptive reuse for existing building?;

2) What are the most significant criteria in decision making for adaptive reuse of existing building?; and

3) What can be done in order to enhance the industrial player's knowledge in adaptive reuse decision making related to green elements?

\section{Methodology}

The three-stage of methodology was conducted to achieve the research aim, these are:

\section{Stage 1 - Identifying the criteria of decision making and Developed the Instrument}

The literature review process started by looking into primary and secondary sources. The primary literature sources included refereed journals, refereed conferences, dissertations/theses, occasional papers and government reports. Secondary sources included text books, trade journals, newspapers and magazines. The five top journals that were reviewed in the search are: i) ScienceDirect; ii) Emerald Group Publishing; iii) Google Scholer; iv) Springer Link; v) Elsevier. These top five journals were selected as they frequently publish scientific scholarly papers in multiple field and they have been ranked highly by several researchers (Maidin, A. B. et al, 2014).

Through an extensive literature review, the decision making criteria were identified (see Table 3) and were used to develop the questionnaire. Type of the instrument developed for this research was a closed-ended questionnaire with taking into consideration the aim and objectives of the study.

Table 3. Measures of decision making criteria

\begin{tabular}{|c|c|c|c|c|c|c|c|}
\hline No & $\begin{array}{l}\text { Measures of decision making } \\
\text { criteria }\end{array}$ & \begin{tabular}{l|} 
Wilkinso \\
n, S. J. \\
(2011)
\end{tabular} & $\begin{array}{l}\text { Bullen \& } \\
\text { Love, } P \\
(2010, \\
2011 \\
\text { a\&b) }\end{array}$ & \begin{tabular}{|l|} 
Wang, \\
H. \& \\
Zeng, Z. \\
(2010)
\end{tabular} & $\begin{array}{l}\text { Barrett, } \\
\text { K. } \\
\text { (2009) }\end{array}$ & $\begin{array}{l}\text { Yildirim } \\
\text {.M. } \\
\text { (2012) }\end{array}$ & $\begin{array}{l}\text { Wilson, } \\
\text { C. A. } \\
\text { (2010) }\end{array}$ \\
\hline 1. & $\begin{array}{l}\text { Target Market/ Profit from } \\
\text { market demand }\end{array}$ & $\mathrm{x}$ & $x$ & $x$ & $x$ & & $\mathrm{x}$ \\
\hline 2. & Sources of finance/Risk & $\mathrm{x}$ & $\mathrm{x}$ & $\mathrm{x}$ & $\mathrm{x}$ & $x$ & $x$ \\
\hline 3. & $\begin{array}{l}\text { Subsidize/ Financial } \\
\text { incentives }\end{array}$ & $\mathrm{x}$ & $\mathrm{x}$ & $\mathrm{x}$ & $x$ & & \\
\hline 4. & $\begin{array}{l}\text { Initial investment and } \\
\text { necessary investment in } \\
\text { future maintenance }\end{array}$ & & $\mathrm{x}$ & $\mathrm{x}$ & & & \\
\hline 5. & $\begin{array}{l}\text { Benefit of exemption/ Tax } \\
\text { concessions }\end{array}$ & $\mathrm{x}$ & $\mathrm{x}$ & $\mathrm{x}$ & & & \\
\hline 6. & Building value & $x$ & $x$ & $x$ & $x$ & & \\
\hline 7. & Site and situation & $x$ & $x$ & $x$ & & & $x$ \\
\hline 8. & Land use plan or zoning & $\mathrm{x}$ & & $\mathrm{x}$ & & & \\
\hline 9. & $\begin{array}{l}\text { Potential environmental } \\
\text { quality of the } \\
\text { surroundings/ } \\
\text { Contamination } \\
\end{array}$ & $\mathrm{x}$ & $\mathrm{x}$ & $\mathrm{x}$ & & $\mathrm{x}$ & $\mathrm{x}$ \\
\hline 10. & Sustainability & $x$ & $\mathrm{x}$ & $\mathrm{x}$ & $x$ & & \\
\hline 11. & $\begin{array}{l}\text { Reduce use of Greenfield } \\
\text { sites }\end{array}$ & & $\mathrm{x}$ & & & & \\
\hline 12. & $\begin{array}{l}\text { Reduction of resource } \\
\text { consumption }\end{array}$ & & $\mathrm{x}$ & & $\mathrm{x}$ & & \\
\hline 13. & $\begin{array}{l}\text { Compatibility of newly } \\
\text { introduced uses with } \\
\text { existing }\end{array}$ & & & $\mathrm{x}$ & & & $\mathrm{x}$ \\
\hline 14. & \begin{tabular}{|l|} 
Public interest \\
\end{tabular} & $\mathrm{x}$ & $\mathrm{x}$ & $\mathrm{x}$ & & & $\mathrm{x}$ \\
\hline 15. & Social and Cultural Value & $\mathrm{x}$ & $\mathrm{x}$ & $\mathrm{x}$ & $x$ & $\mathrm{x}$ & \\
\hline 16. & $\begin{array}{l}\text { Location (proximity to } \\
\text { transport } \\
\text { and amenities, cost of } \\
\text { land) }\end{array}$ & $\mathrm{x}$ & $\mathrm{x}$ & $\mathrm{x}$ & $\mathrm{x}$ & & $\mathrm{x}$ \\
\hline 17. & $\begin{array}{l}\text { Enhancing the role of } \\
\text { communities }\end{array}$ & $\mathrm{x}$ & $\mathrm{x}$ & $\mathrm{x}$ & $\mathrm{x}$ & & $x$ \\
\hline 18. & Retaining a sense of place & & $\mathrm{x}$ & & $\mathrm{x}$ & $x$ & \\
\hline
\end{tabular}




\begin{tabular}{|c|l|c|c|c|c|c|c|}
\hline 19. & $\begin{array}{l}\text { Regional development } \\
\text { policies }\end{array}$ & & $\mathrm{x}$ & $\mathrm{x}$ & & & \\
\hline 20. & $\begin{array}{l}\text { Official Plan and Zoning } \\
\text { regulations }\end{array}$ & $\mathrm{x}$ & $\mathrm{x}$ & & $\mathrm{x}$ & & $\mathrm{x}$ \\
\hline 21. & Building Code & $\mathrm{x}$ & $\mathrm{x}$ & $\mathrm{x}$ & $\mathrm{x}$ & & $\mathrm{x}$ \\
\hline 22. & $\begin{array}{l}\text { Heritage Designated } \\
\text { Buildings }\end{array}$ & $\mathrm{x}$ & $\mathrm{x}$ & $\mathrm{x}$ & & $\mathrm{x}$ & $\mathrm{x}$ \\
\hline 23. & $\begin{array}{l}\text { Development or } \\
\text { Government Incentives }\end{array}$ & $\mathrm{x}$ & $\mathrm{x}$ & & & & $\mathrm{x}$ \\
\hline 24. & $\begin{array}{l}\text { Conditions of integrity and } \\
\text { authenticity }\end{array}$ & & $\mathrm{x}$ & $\mathrm{x}$ & & $\mathrm{x}$ & \\
\hline 25. & $\begin{array}{l}\text { Building system/ } \\
\text { Technological value }\end{array}$ & $\mathrm{x}$ & $\mathrm{x}$ & $\mathrm{x}$ & & & $\mathrm{x}$ \\
\hline 26. & Structural Condition & $\mathrm{x}$ & $\mathrm{x}$ & $\mathrm{x}$ & $\mathrm{x}$ & $\mathrm{x}$ & $\mathrm{x}$ \\
\hline 27. & $\begin{array}{l}\text { Architectural Condition } \\
\text { and Space layout }\end{array}$ & $\mathrm{x}$ & $\mathrm{x}$ & $\mathrm{x}$ & $\mathrm{x}$ & & $\mathrm{x}$ \\
\hline 28. & Site Layout & & $\mathrm{x}$ & & & & $\mathrm{x}$ \\
\hline 29. & Building Suitability & & & & $\mathrm{x}$ & & \\
\hline 30. & Client requirement & & $\mathrm{x}$ & & $\mathrm{x}$ & $\mathrm{x}$ & \\
\hline
\end{tabular}

In order to develop a more comprehensive decision making criteria, the developed questionnaire was submitted to the professional to be discussed and analyzed. For the discussion and analysis, the criteria are grouped according related, measures and concluded by five condensed criteria of decision making are formed. Table 4 presents the criteria of decision making that will use for the conceptual model of study.

Table 4. Decision making criteria

\begin{tabular}{|c|c|}
\hline Main criteria & Sub Criteria \\
\hline Economic & $\begin{array}{l}\text { Target Market/ Profit from market demand } \\
\text { Sources of finance/Risk } \\
\text { Subsidize/ Financial incentives } \\
\text { Initial investment and necessary investment in future } \\
\text { maintenance } \\
\text { Benefit of exemption/ Tax concessions } \\
\text { Building value }\end{array}$ \\
\hline Environment & $\begin{array}{l}\text { Site and situation } \\
\text { Land use plan or zoning } \\
\text { Potential environmental quality of the surroundings/ } \\
\text { Contamination } \\
\text { Sustainability } \\
\text { Reduce use of Greenfield sites } \\
\text { Reduction of resource consumption }\end{array}$ \\
\hline Social & $\begin{array}{l}\text { Compatibility of newly introduced uses with existing } \\
\text { Public interest } \\
\text { Social and Cultural Value } \\
\text { Location (proximity to transport } \\
\text { and amenities, cost of land) } \\
\text { Enhancing the role of communities } \\
\text { Retaining a sense of place }\end{array}$ \\
\hline Legislative & $\begin{array}{l}\text { Regional development policies } \\
\text { Official Plan and Zoning regulations } \\
\text { Building Code } \\
\text { Heritage Designated Buildings } \\
\text { Development or Government Incentives } \\
\text { Conditions of integrity and authenticity }\end{array}$ \\
\hline Architecture & $\begin{array}{l}\text { Building system/ Technological value } \\
\text { Structural Condition } \\
\text { Architectural Condition and Space layout } \\
\text { Site Layout } \\
\text { Building Suitability } \\
\text { Client requirement }\end{array}$ \\
\hline
\end{tabular}

The questionnaire was designed into two sections. The first section needs feedback about respondents' background as well as their experience. It was followed by the research content which is divided into five categories. First category will be touched on Economic Category, followed by Environmental Category and Social Category before ended with Legislative and Architectural Category. The respondents were asked to evaluate the listed criteria based on a 5 Likert Scale with $1=$ Strongly Disagree to $5=$ Strongly Agree. This method will easily compare the respondents' opinion either in positive or negative response according to respective criteria by neutral category included as applied by Addae-dapaah et al. (2009).

The basic questionnaire survey is divided into five major criteria to enhance stakeholders understanding to avoid duplication and redundancy of criteria overlapping each other. However, to achieve the research objectives and to answer research questions, all sections as well as categories (economic, environmental, social, legislative and architecture) will be combined into a single cluster.

\section{Stage 2 - Distribute of Questionnaire}

In order to achieve the objectives of the study, the researcher has identified the stakeholder and sources of information that involved in the adaptive reuse field as a target group. However, there are limitation to get the real numbers for the stakeholders that involve in adaptive reuse. Therefore, the stakeholders from the state under the world heritage is the target respondent. The data collected includes the lists of following stakeholders from different sources such as:

- Lists of Registered Architect (involved in adaptive reuse or equivalent) from Board of Persatuan Arkitek Malaysia (PAM).

- Lists of Registered Valuers from Board of Valuers, Appraisers and Estate Agents Malaysia (BOVAEA) in Penang and Melacca, Malaysia.

- Local authorities (involved in adaptive reuse or equivalent) in Penang and Melacca, Malaysia.

- List of Government Departments (involved in adaptive reuse or equivalent) in Penang and Melacca, Malaysia.

- List of Town Planners (involved in adaptive reuse or equivalent) in Penang and Melacca, Malaysia.

- Lists of Building Owners (involved in adaptive reuse or equivalent) in Penang and Melacca, Malaysia.

From the lists obtained, the researcher will develop a database known as Adaptive Reuse Stakeholders Database which will consist of potential respondents in regards to meet the objectives of the research. This stage is significant to ensure the reliability and the quality of data gathered will meet objectives requirement without prejudice the research analysis and findings.

A total of 65 survey forms that consist of 31 questions regarding decision making criteria complete with 'cover note' started to be distributed at early of December 2015 until end of January 2016. Bullen (2007) points out that the small size of the sample could be considered can reduce the global significance of feedback received with the balancing the value of obtaining opinions from a group of professionals with specialized and specific knowledge of sustainability principles. The collection of data also involved with reminders based on ad-hoc basis to increase the response rate of the research. This form had been sent according to Adaptive Reuse Stakeholders 
Database developed at an earlier stage of the research activities.

A various medium of survey form distribution have been used where majority of them involving online medium through web-based hyperlink known as www.surveymonkey.com. The email address of the sample, where available have been sent through while in the absence of email address and immediate data collection, the researcher has decided to execute by-post and by-hand approach.

\section{Stage 3 - Analysis of Quantitative Data}

Data collected from the questionnaire form will be analyzed using quantitative techniques. Data from the questionnaire survey will be analyzed quantitatively through SPSS software involving the descriptive statistical method. Factor Analysis (FA) technique will be executed to achieve objectives of the study while Reliability Analysis (RA) will be performed accordingly to test the significant findings. The data collected will be formulated and designed in chart, table and other tools.

\section{Conclusions and Further Steps}

This paper has explained the complexity of decision making with regards to adaptive reuse of buildings and the criteria for decision making has been identified by thorough review of literature. This paper also presented the flow of the research activity to be conducted and administered to ensure the objectives of the research can be accomplished. It justifies the application of questionnaire, respondents and in-depth approach of analyzing the data collected to enhance the findings reliability. Thus, it is important for the researcher to ensure the process of research methodology being followed and perform accordingly. Until the end of January 2016, data that has been collected is $95 \%$ and now in the process of analyzing the data collected. This research will be complete within April 2016 for the purpose of obtaining a master's in Green Architecture and the final result of the analysis shall be published in the journal.

\section{References}

1. A. Ghafar Ahmad (2009). Treatment of rising damp and replastering at heritage buildings. Bengkel Bersiri 2009 Konservasi Bangunan Warisan Siri 2: Lepaan Kapur, 17-19hb. Julai 2009, Perak. Dewan Pusat Pelancongan Negeri Perak, Ipoh.

2. Addae-dapaah, K., Hiang, L. K., \& Yen, N. (2009). Sustainability of Sustainable Real Property Development. Journal of Sustainable Real Estate, 1(1), $203-225$.

3. Adeyemi, A., Martin, D., \& Kazim, R. (2014). Sustainable Improvement Strategy for Existing Office Buildings in developing Nations. International Journal of Environment and Sustainable Development, (1), 1-5.
4. Alauddin, K (2014). 'The Development of an Intellectual Capital Framework for Successful Adaptive Re-use', School of Property, Construction and Project Management. Melbourne, RMIT University. Doctor of Philosophy

5. Alauddin, K. \& London. K. (2011). Design Management: Challenges for Adaptive Re- Use, 36th Annual Conference for Australasian University Building Educators Association, 15.

6. Barrett, K. J. (2009). The key issues when choosing adaptation of an existing building over new build. Journal of Building Appraisal, 4(3), 215-223.

7. Bullen, P. a. (2007). Adaptive reuse and sustainability of commercial buildings. Facilities, 25(1/2), 20-31.

8. Bullen, P. a., \& Love, P. E. D. (2010). The rhetoric of adaptive reuse or reality of demolition: Views from the field. Cities, 27(4), 215-224.

9. Bullen, P. a., \& Love, P. E. D. (2011a). Adaptive reuse of heritage buildings. Structural Survey, 29(5), 411-421.

10. Bullen, P., \& Love, P. (2011b). A new future for the past: a model for adaptive reuse decision-making. Built Environment Project and Asset Management, 1, 32-44.

11. Douglas, J. (2006). Building Adaptation. Butterworth-Heinemann, Oxford and Burlington, MA.

12. Enache, M. (2014). Branding the Danish City Is Adaptive Reuse an option? Globalization. Aalborg University, Denmark.

13. Gorgolewski, M. (2008). Designing with reused building components: some challenges. Building Research and Information, 36(2), 175-188.

14. Greenbuildingindex.org. GBI Executive Summary. 26th December 2015, Retrieved from http://www.greenbuildingindex.org/

15. Langston, C. (2011). Modeling Risk Management in Sustainable Construction, 199-209.

16. Maidin, A. B., Shafri, S., \& Ibrahim, S. (2014). Perkembangan dan Kemajuan Penerbitan Jurnal Malaysia: Strategi ke Persada Antarabangsa, (1), 15.

17. Rashid, R. A., Ismail, E. D., \& Abdullah, A. S. (2015). Adaptive Re-Use of Heritage Buildings in Malaysia-A Case Study of Penaga Hotel in Penang. Proceedings of the Colloquium on Administrative Science and Technology, 361-372.

18. Wang, H.-J., \& Zeng, Z.-T. (2010). A multi-objective decision-making process for reuse selection of historic buildings. Expert Systems with Applications, 37(2), 1241-1249.

19. Wilkinson, S. J., James, K., \& Reed, R. (2009). Delivering sustainability through the adaptive reuse of commercial buildings: the Melbourne CBD challenge. Proceedings of the Pacific Rim Real Estate Society 15th Annual Conference, Pacific Rim Real Estate Society (PPRES), (June 2008), 1-19.

20. Wilkinson, S. J., \& Reed, R. G. (2008). The Business Case for incorporating Sustainability in Office Buildings: the Adaptive Reuse of Existing Buildings. Office, 1-18. 
21. Wilson, C. A. (2010). Adaptive Reuse if Industrial Buildings in Toronto, Ontario Evaluating Criteria for Determining Building Selection.

22. Yau, a N. G. H., Implementation, T. H. E., \& Green, O. F. (2010). Universiti Teknologi Malaysia Declaration of Thesis / Undergraduate Paper and Copyright The Implementation of Green Building Restricted Bachelor of Civil Engineering Faculty of Civil Engineering.

23. Yildirim, M. (2012). Assessment of the decisionmaking process for re-use of a historical asset: The example of Diyarbakir Hasan Pasha Khan, Turkey. Journal of Cultural Heritage, 13(4), 379-388.

24. Yung, E. H. K., \& Chan, E. H. W. (2012). Implementation challenges to the adaptive reuse of heritage buildings: Towards the goals of sustainable, low carbon cities. Habitat International, 36(3), 352 361.

25. Zuo, J., \& Zhao, Z. (2014). Green building research current status and future agenda: A review Why? How? How? What? Renewable and Sustainable Energy Reviews, 30, 271-281. 